\title{
Review \\ The Coordination Chemistry of Imidomethanedithiolate Di-anions: A Structural Comparison with Their Dithiocarbamate Analogs
}

\author{
Peter J. Heard ${ }^{1} * \mathbb{D}$, Yee Seng Tan ${ }^{2}$, Chien Ing Yeo ${ }^{2}(\mathbb{D})$ and Edward R. T. Tiekink ${ }^{2, *(D)}$ \\ 1 Chancellery Office, Sunway University, Bandar Sunway 47500, Selangor Darul Ehsan, Malaysia \\ 2 Research Centre for Crystalline Materials, School of Medical and Life Sciences, Sunway University, \\ Bandar Sunway 47500, Selangor Darul Ehsan, Malaysia; yeesengt@sunway.edu.my (Y.S.T.); \\ allyy@sunway.edu.my (C.I.Y.) \\ * Correspondence: pheard@sunway.edu.my (P.J.H.); edwardt@sunway.edu.my (E.R.T.T.)
}

Citation: Heard, P.J.; Tan, Y.S.; Yeo, C.I.; Tiekink, E.R.T. The Coordination Chemistry of Imidomethanedithiolate Di-anions: A Structural Comparison with Their Dithiocarbamate Analogs. Inorganics 2021, 9, 71. https:// doi.org/10.3390/inorganics9090071

Academic Editor: Graeme Hogarth

Received: 13 August 2021

Accepted: 11 September 2021

Published: 14 September 2021

Publisher's Note: MDPI stays neutral with regard to jurisdictional claims in published maps and institutional affiliations.

Copyright: (c) 2021 by the authors. Licensee MDPI, Basel, Switzerland. This article is an open access article distributed under the terms and conditions of the Creative Commons Attribution (CC BY) license (https:// creativecommons.org/licenses/by/ $4.0 /)$.

\begin{abstract}
A review of the coordination chemistry along with the structural features of heavy element complexes of dithiocarbimate di-anions in the form of $\left[(\mathrm{R}) \mathrm{C}=\mathrm{NCS}_{2}\right]^{2-}$ for $\mathrm{R}=\mathrm{CN}$, alkyl, and aryl are described. This class of compound is far less studied compared with the well-explored dithiocarbamate mono-anions formulated as $\left[R\left(\mathrm{R}^{\prime}\right) \mathrm{NCS}_{2}\right]^{-}$for $\mathrm{R} / \mathrm{R}^{\prime}=\mathrm{H}$, alkyl, and aryl. The coordination chemistry of dithiocarbimate di-anions is dominated by a S,S-chelating mode; rare examples of alternative modes of coordination are evident. When comparisons are available, the structural motifs adopted by metal dithiocarbimate complexes match those found for their dithiocarbamate analogs, with only small, non-systematic variations in the M-S bond lengths.
\end{abstract}

Keywords: coordination chemistry; dithiocarbimate; metal imidomethane dithiolates; dithiocarbamate; structural comparison; synthesis; spectroscopy

\section{Introduction}

The complexation of the most well-known 1,1-dithiolate anion, dithiocarbamate, with a general formula of $\left[R\left(R^{\prime}\right) N_{C S}\right]^{-}$for $R / R^{\prime}=H$, alkyl, and aryl, by heavy elements such as transition metals, main group elements and lanthanides and actinides remains a mainstay in coordination chemistry. This assertion is no better vindicated than by a search of the Cambridge Structural Database [1], which reveals over 4300 entries containing dithiocarbamate anions, esters, or ligands. This importance is also borne out by the regular appearance of authoritative bibliographic reviews of the coordination chemistry of dithiocarbamates [2-7], reviews of specific aspects of their coordination and supramolecular chemistry [8-13], and recently of their mono- and di-seleno analogs [14].

A key feature of the coordination chemistry of dithiocarbamate anions is the significant contribution of resonance structure (III) (Figure 1). Structure (III) contributes $40 \%$ to the overall electronic structure of dithiocarbamate anions, while resonance forms (I) and (II) each contributes $30 \%$. This electronic distribution readily explains the ability of dithiocarbamate ligands to complexify heavy element centers and to stabilize higher-than-usually observed oxidation states [2-7]. While not the focus of the present survey, canonical form (III) also accounts for the ability of the $\mathrm{MS}_{2} \mathrm{C}$ chelate ring with significant metalloaromatic characteristics [15] to function as an acceptor for structure-directing $\mathrm{C}-\mathrm{H} \cdots \pi$ (chelate ring) interactions with significant energy of stabilization in, for example, over a third (37\%) of the crystals of homoleptic nickel dithiocarbamate complexes [16-18]. 


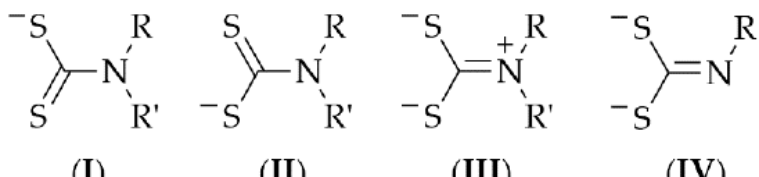

(I)

(II)

(III)

(IV)

Figure 1. (I-III) Canonical forms of the dithiocarbamate mono-anion $\left[R\left(\mathrm{R}^{\prime}\right) \mathrm{NCS}_{2}\right]^{-}, \mathrm{R} / \mathrm{R}^{\prime}=\mathrm{H}$, alkyl, and aryl and (IV) the electronic structure of the dithiocarbimate di-anion $\left[(\mathrm{R}) \mathrm{C}=\mathrm{NCS}_{2}\right]^{2-}, \mathrm{R}=\mathrm{CN}$, alkyl, and aryl.

By contrast to the well-developed dithiocarbamate chemistry, the coordination chemistry of the closely related dithiocarbimate ligands (i.e., $\left[(\mathrm{R}) \mathrm{C}=\mathrm{NCS}_{2}\right]^{2-}$ ) is significantly less well-explored. The key differences between dithiocarbamate and dithiocarbimate ligands is the presence of just one N-bound substituent in the latter and the consequent increase in the formal sulfur-bound negative charge. This results in electronic structure (IV), shown in Figure 1. The aim of the present survey is to ascertain the structural motifs formed by dithiocarbimate ligands bound to heavy elements and to relate these, where possible, to those formed by dithiocarbamate analogs in terms of structural motif and bonding characteristics.

\section{General Aspects of Dithiocarbimate Ligands}

Synthetic procedures to form dithiocarbimate ligands mimic, at least to a first approximation, those employed to form dithiocarbamate ligands. Thus, while dithiocarbamate ligands may be isolated from the reaction of an appropriate amine with carbon disulfide in the presence of base, a common dithiocarbimate ligand, namely dipotassium cyanodithioimidocarbonate, can be formed from the reaction of cyanamide (aminomethanenitrile), carbon disulfide, and potassium ethoxide [19]. Other routes are from the reaction of dipotassium cyanamide and carbon disulfide [20] and the reaction of xanthane hydride and a base [21]. The synthesis of dithiocarbimate complexes can also be achieved in a manner similar to the in situ preparation of dithiocarbamate complexes (i.e., without the isolation of the original salt). For example, $\left(\mathrm{Et}_{3} \mathrm{P}\right)_{2} \mathrm{Pt}\left[\mathrm{S}_{2} \mathrm{C}=\mathrm{N}\left(\mathrm{CH}_{2} \mathrm{Ph}\right)\right]$ was prepared from the reaction of $\left(\mathrm{Et}_{3} \mathrm{P}\right)_{2} \mathrm{PtCl}_{2}$ with the primary amine, $\mathrm{PhCH}_{2} \mathrm{NH}_{2}$, and carbon disulfide. This product can be converted to the dithiocarbamate species upon the addition of $\mathrm{HCl}$ to form $\left\{\left(\mathrm{Et}_{3} \mathrm{P}\right)_{2} \mathrm{Pt}\left[\mathrm{S}_{2} \mathrm{C}=\mathrm{N}(\mathrm{H}) \mathrm{CH}_{2} \mathrm{Ph}\right]\right\} \mathrm{Cl}$ [22]. Another general procedure for the formation of dithiocarbimate complexes involves the conversion of a pre-formed dithiocarbamate complex to the dithiocarbimate derivative. As an example of this method, $\left[\mathrm{NBu}_{4}\right]_{2}\left\{\mathrm{Pd}\left[\mathrm{S}_{2} \mathrm{C}=\mathrm{N}\left(\mathrm{C}_{6} \mathrm{H}_{4} \mathrm{NH}_{2}-4\right)\right]_{2}\right\}$ [23] was prepared from the reaction of $\mathrm{Pd}\left[\mathrm{S}_{2} \mathrm{CN}(\mathrm{H}) \mathrm{C}_{6} \mathrm{H}_{4} \mathrm{NH}_{2}-4\right]_{2}$ with excess $\mathrm{NaOH}$, whose function is to abstract the $\mathrm{S}_{2} \mathrm{CN}$-bound proton from the dithiocarbamate complex, followed by the addition of tetrabutylammonium bromide to yield the dithiocarbimate complex.

The infrared spectra of dithiocarbimate complexes display a characteristic $v(\mathrm{C}=\mathrm{NR})$ stretch in the broad region of 1310-1690 $\mathrm{cm}^{-1}$ (mean $=1543 \mathrm{~cm}^{-1}$; standard deviation $\left.=61 \mathrm{~cm}^{-1}\right)$. The frequency of the $\mathrm{C}=\mathrm{N}$ stretch is lowest for the uncomplexed ligand $\left[(\mathrm{R}) \mathrm{C}=\mathrm{NCS}_{2}\right]^{2-}$, with the free ligand $\mathrm{K}_{2}\left[\mathrm{~S}_{2} \mathrm{C}=\mathrm{N}(\mathrm{CN})\right]$ displaying a $v(\mathrm{C}=\mathrm{N})$ band at $1315 \mathrm{~cm}^{-1}$ [19]. By contrast, the highest stretching frequencies are found in complexes when the dithiocarbimate ligand is bridging, such as in $\left[\mathrm{CpMo}(\mathrm{CO})_{2} \mathrm{Mn}(\mathrm{CO})_{3}\right]\left[\mathrm{S}_{2} \mathrm{C}=\mathrm{N}(\mathrm{tBu})\right]$, where the $\mathrm{C}=\mathrm{N}$ stretching band is observed at $1684 \mathrm{~cm}^{-1}$ [24]. When these extreme cases are excluded, the $\mathrm{C}=\mathrm{N}$ bands are found in the narrower window of $1480-1590 \mathrm{~cm}^{-1}$, with the mean being $1557 \mathrm{~cm}^{-1}$.

The majority of dithiocarbimate complexes for which ${ }^{1} \mathrm{H}$ NMR data are available are either palladium(II) or platinum(II) complexes. In the ${ }^{1} \mathrm{H}$ NMR of these complexes, the protons of the $\alpha$-carbon atom $\left(\mathrm{HCN}=\mathrm{CS}_{2}\right)$, where present, are found in the 3.10-5.60 ppm region, with a mean of $4.56 \mathrm{ppm}$, which compares to the $1.80-4.55 \mathrm{ppm}$ region recently reported for related platinum group metal dithiocarbamate complexes [7]. As with the dithiocarbamates, the shifts were generally observed to be greater in the palladium(II) com- 
plexes than in the platinum(II) complexes. The quaternary carbon atom $\mathrm{RNCS}_{2}$ resonates over the broad range of 140-230 ppm, with the greatest shifts being found in the cationic complexes. The free ligand $\mathrm{K}_{2}\left[\mathrm{~S}_{2} \mathrm{C}=\mathrm{N}(\mathrm{CN})\right]$, for example, has a reported shift of $228 \mathrm{ppm}$. More typically, the shifts are observed in the region of 140-185 ppm (mean $=171 \mathrm{ppm})$, which is somewhat lower than that observed in dithiocarbamate complexes [7].

A search of the Cambridge Structural Database (CSD, version 5.42) [1] with the aid of ConQuest (version 2.0.4) [25] was conducted, whereby structures bearing a $\mathrm{S}_{2} \mathrm{C}=\mathrm{NC}$ moiety, the key characteristic of a dithiocarbimate residue, complexed to a heavy element were identified; no other restrictions were applied. This retrieved 43 distinct "hits". The crystallographic diagrams were generated using the data in the Crystallographic Information File deposited for each structure using the DIAMOND program [26].

\section{Crystal Structures: Analysis of CSD Data}

\subsection{Coordination Chemistry of Dithiocarbimate Di-Anions}

The following discussion is arranged so that the available crystal structures are described in order of the Group of the Periodic Table they belong to. For completeness, structures of the main group element compounds are also included.

\subsubsection{Cr Group}

There are five dithiocarbimate structures in this category, and these adopt four quite distinct structural motifs. This category also includes the description of the sole example of a heterometallic complex. The first structure to be described is a di-nuclear molybdenum complex found in the salt $\left[\mathrm{NEt}_{4}\right]_{2}\left\{\mathrm{Mo}(=\mathrm{S})\left(\mu_{2}-\mathrm{S}\right)\left[\mathrm{S}_{2} \mathrm{C}=\mathrm{N}(\mathrm{Ph})\right]\right\}_{2}$, isolated as a DMF hemisolvate (1) [27]. As shown in Figure 2a, the di-anion features two molybdenum(V) centers bridged by two $\mu_{2}$-sulfido ligands, and each metal atom is terminally bound by thioxide and chelating phenyl-dithiocarbimate di-anions (Mo-S: $2 \times 2.42$ and $2.46 \AA$, respectively). While the di-anion lacks crystallographic symmetry, the $\mathrm{Mo}=\mathrm{S}$ residues are approximately syn, with the pseudo $\mathrm{S}=\mathrm{Mo} \cdots \mathrm{Mo}=\mathrm{S}$ torsion angle being $6.6^{\circ}$. The penta-coordinated molybdenum atoms defined by the $S_{5}$ donor set approximate square pyramidal geometries with the thioxide-sulfur atoms in the apical positions, and the Mo $\cdots$ Mo separation is $2.86 \AA$. The second molybdenum complex is also di-nuclear, but it is organometallic: $[\mathrm{CpMo}(\mathrm{SMe})]_{2}\left[\mathrm{~S}_{2} \mathrm{C}=\mathrm{N}\left(2,6-\mathrm{Me}_{2} \mathrm{C}_{6} \mathrm{H}_{3}\right)\right]$ (2) [28]. The two molybdenum centers are bridged by a pair of $\mu_{2}$-methylthiolate ligands, and each is also bound by a $C p$ ligand (Figure $2 b$ ). The 2,6-dimethylphenyldithiocarbimate di-anion is also $\mu_{2}$-bridging, as each sulfur atom forms a bond to both molybdenum atoms, with the bridges being symmetric (Mo-S: 2.45 and $2.46 \AA$ for the first Mo atoms and $2 \times 2.47 \AA$ for the second).

The next two structures are tungsten species: $\left(\mathrm{Ph}_{2} \mathrm{P}\left(\mathrm{CH}_{2}\right)_{2} \mathrm{P}(\mathrm{Ph}) \mathrm{C}_{6} \mathrm{H}_{4} \mathrm{P}(\mathrm{Ph})\left(\mathrm{CH}_{2}\right)\right.$ $\left.{ }_{2} \mathrm{PPh}_{2}\right) \mathrm{W}\left(\mathrm{C} \equiv \mathrm{NC}_{6} \mathrm{H}_{4} \mathrm{Me}-4\right)\left[\mathrm{S}_{2} \mathrm{C}=\mathrm{N}\left(4\right.\right.$-tolyl)].THF (3) [29] and $\left(\mathrm{Ph}_{2} \mathrm{P}\left(\mathrm{CH}_{2}\right)_{2} \mathrm{P}(\mathrm{Ph}) \mathrm{C}_{6} \mathrm{H}_{4} \mathrm{P}(\mathrm{Ph})\right.$ $\left.\left.\left(\mathrm{CH}_{2}\right)_{2} \mathrm{PPh}_{2}\right) \mathrm{W}\left(\mathrm{C} \equiv \mathrm{NC}_{6} \mathrm{H}_{4} \mathrm{Cl}-4\right)\left[\mathrm{S}_{2} \mathrm{C}=\mathrm{NC}_{6} \mathrm{H}_{4} \mathrm{Cl}-4\right)\right] .2 .25(\mathrm{DCM})$ (4) [29]. The molecular structure of the complex in 3 is represented in Figure 2c. Here, the tungsten is tetra-coordinated by the four phosphorus atoms of the meso-1,2- $\mathrm{C}_{6} \mathrm{H}_{4}\left(\mathrm{PPhCH}_{2} \mathrm{CH}_{2} \mathrm{PPh}_{2}\right)_{2}$ ligand as well as the carbon atom of the isocyanide ligand, and then it is also S,S-chelated by the 4-tolyldithiocarbimate ligand (W-S: 2.55 and $2.56 \AA$ ). The resulting seven-coordinate geometry is based on a pentagonal bipyramid, with the axial positions occupied by the isocyanide- $C$ and one of the sulfur atoms. As noted from Figure 2c, the terminal 4-tolyl ligand may be considered anti with respect to the axial-S atom. In the 4-chlorophenyl derivative 4, three independent molecules comprise the asymmetric unit. While for each of these the coordination geometry is essentially the same as that shown in Figure 2c, the terminal 4-chlorophenyl group is described as being syn to the axially bound sulfur atom.

The heterometallic complex, comprising molybdenum and manganese atoms, is formulated as $\left[\mathrm{CpMo}(\mathrm{CO})_{2} \mathrm{Mn}(\mathrm{CO})_{3}\right]\left[\mathrm{S}_{2} \mathrm{C}=\mathrm{N}(\mathrm{tBu})\right](5)[24]$ and bears a resemblance to the structure of 2 . As is apparent from Figure $2 \mathrm{~d}$, the molybdenum atom is coordinated by two carbonyl ligands and a $\mathrm{Cp}$, while the manganese center carries three carbonyls. The 
t-butyl-dithiocarbimate ligand is $\mu_{2}$-bridging, as each sulfur atom is connected to both the molybdenum and manganese atoms (Mo-S: 2.46 and $2.47 \AA$ and Mn-S: $2 \times 2.33 \AA$ ).

(a)
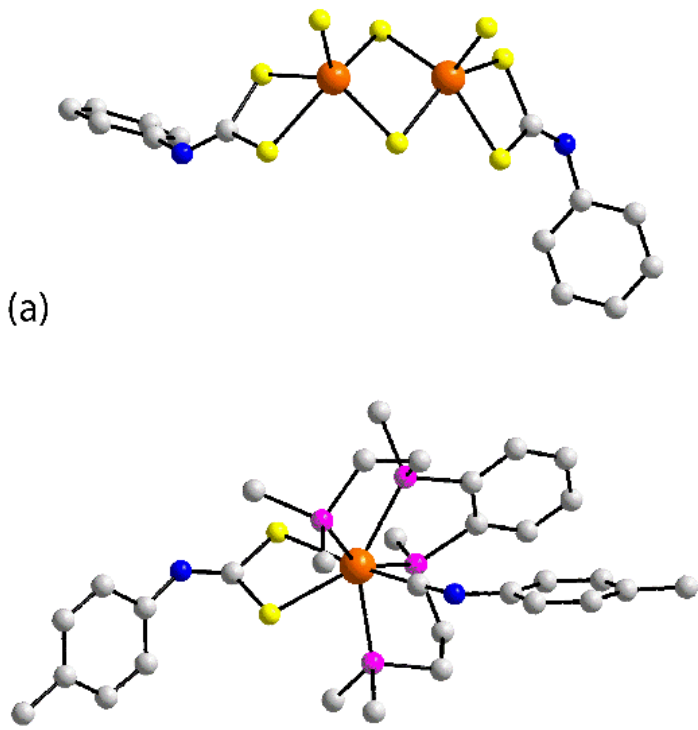

(c)
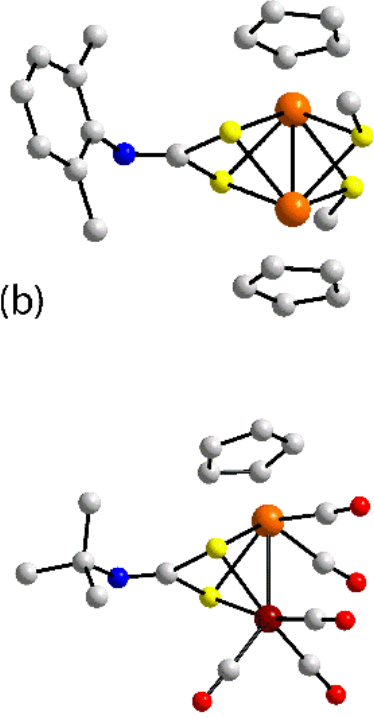

(d)

Figure 2. Molecular structures of (a) the $\left\{\mathrm{Mo}(=\mathrm{S})\left(\mu_{2}-\mathrm{S}\right)\left[\mathrm{S}_{2} \mathrm{C}=\mathrm{N}(\mathrm{Ph})\right]\right\}_{2}{ }^{2-}$ di-anion in 1, (b) $[\mathrm{CpMo}(\mathrm{SMe})]_{2}\left[\mathrm{~S}_{2} \mathrm{C}=\mathrm{N}\left(2,6-\mathrm{Me}_{2} \mathrm{C}_{6} \mathrm{H}_{3}\right)\right](2)$, (c) $\left(\mathrm{Ph}_{2} \mathrm{P}\left(\mathrm{CH}_{2}\right)_{2} \mathrm{P}(\mathrm{Ph}) \mathrm{C}_{6} \mathrm{H}_{4} \mathrm{P}(\mathrm{Ph})\left(\mathrm{CH}_{2}\right)_{2} \mathrm{PPh}_{2}\right) \mathrm{W}(\mathrm{C} \equiv$ $\left.\mathrm{NC}_{6} \mathrm{H}_{4} \mathrm{Me}-4\right)\left[\mathrm{S}_{2} \mathrm{C}=\mathrm{N}(4\right.$-tolyl) $]$ in 3, and (d) $\left[\mathrm{CpMo}(\mathrm{CO})_{2} \mathrm{Mn}(\mathrm{CO})_{3}\right]\left[\mathrm{S}_{2} \mathrm{C}=\mathrm{N}(\mathrm{tBu})\right]$ (5). The color code in this and subsequent diagrams is as follows: primary metal center = orange; manganese $=$ brown; sulfur = yellow; phosphorus = pink; oxygen = red; nitrogen = blue; and carbon = gray. Hydrogen atoms are omitted for clarity. In (c), only the ipso carbon atoms of the phosphorus-bound phenyl groups are shown.

\subsubsection{Mn Group}

Both structures in this category contain rhenium. In the anion of $\left[\mathrm{Ph}_{4} \mathrm{P}\right]\left\{\left(\mathrm{S}_{4}\right) \operatorname{Re}(=\mathrm{S}) \mathrm{The}\right.$ heterometallic complex, comprising molybdenum and manganese atoms, is formulated as $\left[\mathrm{CpMo}(\mathrm{CO})_{2} \mathrm{Mn}(\mathrm{CO})_{3}\right]\left[\mathrm{S}_{2} \mathrm{C}=\mathrm{N}(\mathrm{tBu})\right](5)$ [24] and bears a resemblance to the structure of 2. As is apparent from Figure 2d, the molybdenum atom is coordinated by two carbonyl ligands and a $\mathrm{Cp}$, while the manganese center carries three carbonyls. The t-butyldithiocarbimate ligand is $\mu_{2}$-bridging, as each sulfur atom is connected to both the molybdenum and manganese atoms (Mo-S: 2.46 and $2.47 \AA$ and $\mathrm{Mn}-\mathrm{S}: 2 \times 2.33 \AA$ ). $\left.\left[\mathrm{S}_{2} \mathrm{C}=\mathrm{N}(\mathrm{Me})\right]\right\}$ (6) [30] (Figure 3a), the rhenium center is chelated by each of the tetra-sulfide and methyldithiocarbimate (Re-S: $2 \times 2.34 \AA$ ) ligands, with the final (apical) site in the square pyramidal geometry occupied by the terminally bound thioxide ligand. Greater congestion is evident in the structure of $\left[\left(2,6-(\mathrm{iPr})_{2} \mathrm{C}_{6} \mathrm{H}_{3}\right) \mathrm{NC}(\mathrm{Me})=\mathrm{C}(\mathrm{H}) \mathrm{C}(\mathrm{Me})=\mathrm{N}\left(2,6-(\mathrm{iPr})_{2} \mathrm{C}_{6} \mathrm{H}_{3}\right] \mathrm{Re}[=\mathrm{N}(2,6-\right.$ $\left.\left.(\mathrm{iPr})_{2} \mathrm{C}_{6} \mathrm{H}_{3}\right)\right]\left[\mathrm{S}_{2} \mathrm{C}=\mathrm{N}(\mathrm{Mes})\right]$ (7) [31] (Figure 3b). The rhenium atom in 7 is chelated by the bulky $\beta$-diketiminate ligand and terminally coordinated by the $\mathrm{N}$-bound imide ligand, with the $\mathrm{N}_{3} \mathrm{~S}_{2}$ donor set completed by the chelating (2,4,6-trimethylphenyl)-dithiocarbimate ligand (Re-S: 2.33 and $2.35 \AA$ ). The coordination geometry is based on a square pyramid with the imide-nitrogen atom in the apical position.

\subsubsection{Fe Group}

The only structure in this category is $\left[(\mathrm{CO})_{2} \mathrm{Fe}(\mathrm{dppm}) \mathrm{Fe}(\mathrm{CO})_{2}\right]\left[\mathrm{S}_{2} \mathrm{C}=\mathrm{N}(4\right.$-tolyl)] (8) [32] (Figure 4), where dppm is $\mathrm{Ph}_{2} \mathrm{PCH}_{2} \mathrm{PPh}_{2}$. The di-nuclear structure resembles those previously described by $\mathbf{2}$ and $\mathbf{5}$ (Figure 2). The iron atoms are bridged by the bidentate bridging dppm ligand, and each also carries two carbonyl ligands. Each sulfur atom of the 4-tolyl-dithiocarbimate ligand connects to both iron atoms (Fe-S: 2.26 and $2.27 \AA$ and 
$2 \times 2.30 \AA$ ). The small disparity in the Fe-S bond lengths is related to the trans effect, with the longer distances having the sulfur atoms approximately trans to the carbonyl ligands.

(a)

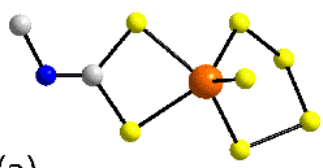

Figure 3. Molecular structures of (a) the $\left\{\left(\mathrm{S}_{4}\right) \operatorname{Re}(=\mathrm{S})\left[\mathrm{S}_{2} \mathrm{C}=\mathrm{N}(\mathrm{Me})\right]\right\}^{-}$anion in $\mathbf{6}$ and $(\mathbf{b})[(2,6-$ $\left.(\mathrm{iPr})_{2} \mathrm{C}_{6} \mathrm{H}_{3}\right) \mathrm{NC}(\mathrm{Me})=\mathrm{C}(\mathrm{H}) \mathrm{C}(\mathrm{Me})=\mathrm{N}\left(2,6-(\mathrm{iPr})_{2} \mathrm{C}_{6} \mathrm{H}_{3}\right] \operatorname{Re}\left[=\mathrm{N}\left(2,6-(\mathrm{iPr})_{2} \mathrm{C}_{6} \mathrm{H}_{3}\right)\right]\left[\mathrm{S}_{2} \mathrm{C}=\mathrm{N}(\mathrm{Mes})\right](7)$.

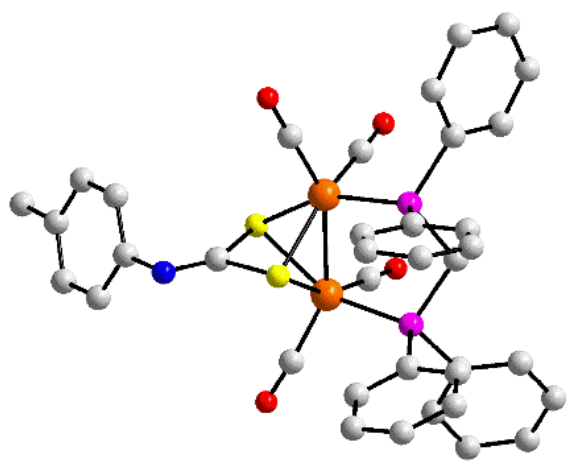

Figure 4. Molecular structure of $\left[(\mathrm{CO})_{2} \mathrm{Fe}(\mathrm{dppm}) \mathrm{Fe}(\mathrm{CO})_{2}\right]\left[\mathrm{S}_{2} \mathrm{C}=\mathrm{N}(4\right.$-tolyl) $]$ (8).

\subsubsection{Co Group}

The crystallographic asymmetric unit of the organometallic $\left\{\mathrm{Cp}^{*} \mathrm{Rh}\left[\mathrm{S}_{2} \mathrm{C}=\mathrm{N}(\mathrm{CN})\right]\right\}_{2}$ compound comprises two independent di-nuclear molecules, each with two-fold symmetry, and two chloroform molecules of solvation (9) [19]. One of the independent di-nuclear molecules is shown in Figure 5 and shows that the independent cyano-dithiocarbimate chelates one rhodium atom (Rh-S: 2.36 and $2.40 \AA$ ) and simultaneously bridges the rhodium atom related by two-fold symmetry (Rh-S: $2.42 \AA$ ); the longer Rh-S bond lengths involve the sulfur-bridging atom. A consequence of the symmetry is that the two cyanodithiocarbimate ligands lie on the same side of the central $\mathrm{Rh}_{2} \mathrm{~S}_{2}$ core.

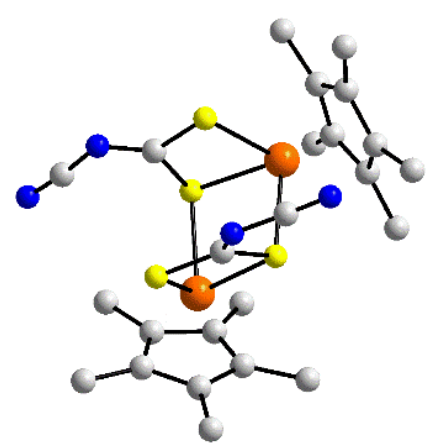

Figure 5. Molecular structure of one of the independent molecules of $\left\{C \mathrm{p}^{*} \mathrm{Rh}\left[\mathrm{S}_{2} \mathrm{C}=\mathrm{N}(\mathrm{CN})\right]\right\}_{2}$ in 9 . 


\subsubsection{Ni Group}

By far, the most represented group of elements complexed by dithiocarbimate ligands is that of the nickel-triad elements. A list of structures and key geometric parameters for these are given in Table 1. The least-represented structures are those containing nickel, but the two observed structural motifs are representative of all structures in this category, consistent with a high degree of homogeneity. There are two bis-chelated nickel(II) dianions, namely $\left\{\mathrm{Ni}\left[\mathrm{S}_{2} \mathrm{C}=\mathrm{N}(\mathrm{CN})\right]_{2}\right\}^{2-}$ (10) [21] and $\left\{\mathrm{Ni}\left[\mathrm{S}_{2} \mathrm{C}=\mathrm{N}\left(\mathrm{C}_{6} \mathrm{H}_{4} \mathrm{CN}-4\right)\right]_{2}\right\}^{2-}$ (11) [33], and these comprise the first structural motif. The di-anion in $\mathbf{1 0}$ is illustrated in Figure 6a. The nickel(II) center in $\mathbf{1 0}$ is located on an inversion center, as is the case for the di-anion in 11. The four sulfur atoms define a square planar geometry, and the $\mathrm{Ni}-\mathrm{S}$ bond lengths are chemically equivalent (Table 1 ). The second structural motif is observed in neutral (dppe) $\mathrm{Ni}\left[\mathrm{S}_{2} \mathrm{C}=\mathrm{N}(\mathrm{CN})\right]$ (12) [34], where dppe is $\mathrm{Ph}_{2} \mathrm{PCH}_{2} \mathrm{CH}_{2} \mathrm{PPh}_{2}$. Two independent molecules comprise the asymmetric unit, but they differ only trivially. A representative molecule is shown in Figure 6b. The nickel atom in $\mathbf{1 2}$ is chelated by both the diphosphane and cyano-dithiocarbimate ligand, where the latter forms symmetric $\mathrm{Ni}-\mathrm{S}$ bond lengths, ranging from 2.20 to $2.22 \AA$ (Table 1 ).

Table 1. Structural data for the nickel-triad elements complexed by dithiocarbimate ligands.

\begin{tabular}{|c|c|c|c|c|}
\hline No. & Formulation & M-S (Å) & $\begin{array}{c}\text { CSD } \\
\text { Refcode }\end{array}$ & Ref. \\
\hline 10 & {$[\mathrm{AsPh}]_{2}\left\{\mathrm{Ni}\left[\mathrm{S}_{2} \mathrm{C}=\mathrm{N}(\mathrm{CN})\right]_{2}\right\}$} & 2.19 and 2.19 & PASCNN & [21] \\
\hline 11 & {$\left[\mathrm{NBu}_{4}\right]_{2}\left\{\mathrm{Ni}\left[\mathrm{S}_{2} \mathrm{C}=\mathrm{N}\left(\mathrm{C}_{6} \mathrm{H}_{4} \mathrm{CN}-4\right)\right]_{2}\right\}$} & 2.20 and 2.20 & NILTOR & [33] \\
\hline $12^{\mathrm{a}}$ & (dppe) $\mathrm{Ni}\left[\mathrm{S}_{2} \mathrm{C}=\mathrm{N}(\mathrm{CN})\right]$ & $\begin{array}{l}2.20 \text { and } 2.21 \\
2.22 \text { and } 2.22\end{array}$ & PEZTIA & [34] \\
\hline 13 & {$\left[\mathrm{Ph}_{4} \mathrm{P}\right]_{2}\left\{\mathrm{Pd}\left[\mathrm{S}_{2} \mathrm{C}=\mathrm{N}(\mathrm{CN})\right]_{2}\right\}$} & $\begin{array}{l}2.31 \text { and } 3.33 \\
2.32 \text { and } 2.32\end{array}$ & BENKEL & [19] \\
\hline 14 & {$\left[\mathrm{NBu}_{4}\right]_{2}\left\{\mathrm{Pd}\left[\mathrm{S}_{2} \mathrm{C}=\mathrm{N}\left(\mathrm{C}_{6} \mathrm{H}_{4} \mathrm{NH}_{2}-4\right)\right]_{2}\right\}$} & 2.31 and 3.33 & ZUNFOD & [23] \\
\hline 15 & $\left(\mathrm{Me}_{3} \mathrm{P}\right)_{2} \mathrm{Pd}\left[\mathrm{S}_{2} \mathrm{C}=\mathrm{N}(\mathrm{Ph})\right]$ & 2.31 and 2.34 & EJUGAS & [35] \\
\hline 16 & $\left(\mathrm{Et}_{3} \mathrm{P}\right)_{2} \mathrm{Pd}\left[\mathrm{S}_{2} \mathrm{C}=\mathrm{N}\left(\mathrm{CH}_{2} \mathrm{Ph}\right)\right]$ & 2.31 and 2.33 & CICKII & [22] \\
\hline 17 & $\left(\mathrm{Me}_{2} \mathrm{PhP}\right)_{2} \mathrm{Pt}\left[\mathrm{S}_{2} \mathrm{C}=\mathrm{N}(\mathrm{Ph})\right]$ & 2.32 and 2.33 & EJUGEW & [35] \\
\hline 18 & $\left(\mathrm{Ph}_{3} \mathrm{P}\right)_{2} \mathrm{Pd}\left[\mathrm{S}_{2} \mathrm{C}=\mathrm{N}(\mathrm{C}(=\mathrm{O}) \mathrm{OEt})\right]$ & 2.32 and 2.34 & PECTPD & [36] \\
\hline 19 & $\left(\mathrm{Ph}_{3} \mathrm{P}\right)_{2} \mathrm{Pd}\left[\mathrm{S}_{2} \mathrm{C}=\mathrm{N}(2-\mathrm{py})\right]$ & 2.32 and 2.33 & QAHQUN & [37] \\
\hline 20 & $\left(\mathrm{Et}_{3} \mathrm{P}\right)_{2} \mathrm{Pt}\left[\mathrm{S}_{2} \mathrm{C}=\mathrm{N}\left(\mathrm{CH}_{2} \mathrm{Ph}\right)\right]$ & 2.33 and 2.34 & CICKEE & [22] \\
\hline 21 & $\left(\mathrm{Me}_{2} \mathrm{PhP}\right)_{2} \mathrm{Pt}\left[\mathrm{S}_{2} \mathrm{C}=\mathrm{N}(\mathrm{Ph})\right]$ & 2.34 and 2.34 & EGULUO & [38] \\
\hline 22 & $\left(\mathrm{Me}_{2} \mathrm{PhP}\right)_{2} \mathrm{Pt}\left[\mathrm{S}_{2} \mathrm{C}=\mathrm{N}(\mathrm{CN})\right]$ & 2.35 and 2.36 & BENKIP & [19] \\
\hline 23 & $\left(\mathrm{Ph}_{3} \mathrm{P}\right)_{2} \mathrm{Pt}\left[\mathrm{S}_{2} \mathrm{C}=\mathrm{N}(\mathrm{Me})\right]$ & 2.32 and 2.34 & SOQYEC & [39] \\
\hline $24^{a, b}$ & $\left(\mathrm{Et}_{2} \mathrm{P}\left(\mathrm{CH}_{2}\right)_{2} \mathrm{PEt}_{2}\right) \mathrm{Pd}\left[\mathrm{S}_{2} \mathrm{C}=\mathrm{N}(\mathrm{CH}(\mathrm{Me}) \mathrm{Ph})\right]$ & $\begin{array}{l}2.32 \text { and } 2.34 \\
2.33 \text { and } 2.33\end{array}$ & NOQZEA & [40] \\
\hline $25^{a, c}$ & $\left(\mathrm{Et}_{2} \mathrm{P}\left(\mathrm{CH}_{2}\right)_{2} \mathrm{PEt}_{2}\right) \mathrm{Pd}\left[\mathrm{S}_{2} \mathrm{C}=\mathrm{N}(\mathrm{CH}(\mathrm{Me}) \mathrm{Ph})\right]$ & $\begin{array}{l}2.32 \text { and } 2.33 \\
2.33 \text { and } 2.33\end{array}$ & NOQZIE & [40] \\
\hline 26 & $\begin{array}{c}\left(\mathrm{Ph}_{2} \mathrm{P}\left(\mathrm{CH}_{2}\right)_{3} \mathrm{PPh}_{2}\right) \mathrm{Pt}\left[\mathrm{S}_{2} \mathrm{C}=\mathrm{N}(\mathrm{Ph})\right] \cdot \mathrm{CH}_{2} \mathrm{Cl}_{2} \\
\mathrm{H}_{2} \mathrm{O}\end{array}$ & 2.34 and 2.34 & EGUMAV & [38] \\
\hline 27 & $(\mathrm{dppf}) \operatorname{Pt}\left[\mathrm{S}_{2} \mathrm{C}=\mathrm{N}(\mathrm{CN})\right]$ & 2.34 and 2.35 & BENKOV & [19] \\
\hline
\end{tabular}

Two di-anionic palladium(II) complex molecules adopt the square planar motif illustrated in Figure 6a: $\left\{\mathrm{Pd}\left[\mathrm{S}_{2} \mathrm{C}=\mathrm{N}(\mathrm{CN})\right]_{2}\right\}^{2-}$ in $13[19]$ and $\left\{\mathrm{Pd}\left[\mathrm{S}_{2} \mathrm{C}=\mathrm{N}\left(\mathrm{C}_{6} \mathrm{H}_{4} \mathrm{NH}_{2}-4\right)\right]\right\}^{2-}$ in 14 [23]. The palladium atoms in the two independent di-anions in the asymmetric unit of $\mathbf{1 3}$ and in the di-anion in $\mathbf{1 4}$ are each located on a center of inversion. Despite having monodentate phosphane ligands, the molecules in each of $\left(\mathrm{Me}_{3} \mathrm{P}\right)_{2} \mathrm{Pd}\left[\mathrm{S}_{2} \mathrm{C}=\mathrm{N}(\mathrm{Ph})\right]$ (15) [35], $\left(\mathrm{Et}_{3} \mathrm{P}\right)_{2} \mathrm{Pd}\left[\mathrm{S}_{2} \mathrm{C}=\mathrm{N}\left(\mathrm{CH}_{2} \mathrm{Ph}\right)\right](\mathbf{1 6})$ [22], $\left(\mathrm{Me}_{2} \mathrm{PhP}\right)_{2} \mathrm{Pt}\left[\mathrm{S}_{2} \mathrm{C}=\mathrm{N}(\mathrm{Ph})\right](\mathbf{1 7})[35],\left(\mathrm{Ph}_{3} \mathrm{P}\right)_{2} \mathrm{Pd}\left[\mathrm{S}_{2} \mathrm{C}=\mathrm{N}\right.$ $(\mathrm{C}(=\mathrm{O}) \mathrm{OEt})](18)$ [36], and $\left(\mathrm{Ph}_{3} \mathrm{P}\right)_{2} \mathrm{Pd}\left[\mathrm{S}_{2} \mathrm{C}=\mathrm{N}(2-\mathrm{py})\right](19)$ [37] adopt the same motif shown in Figure 6b. In the same way, the platinum(II) complexes with two monodentate phosphane ligands (i.e., $\left(\mathrm{Et}_{3} \mathrm{P}\right)_{2} \mathrm{Pt}\left[\mathrm{S}_{2} \mathrm{C}=\mathrm{N}\left(\mathrm{CH}_{2} \mathrm{Ph}\right)\right]$ (20) [22], $\left(\mathrm{Me}_{2} \mathrm{PhP}\right)_{2} \mathrm{Pt}\left[\mathrm{S}_{2} \mathrm{C}=\mathrm{N}(\mathrm{Ph})\right]$ (21) [38], $\left(\mathrm{Me}_{2} \mathrm{PhP}\right)_{2} \mathrm{Pt}\left[\mathrm{S}_{2} \mathrm{C}=\mathrm{N}(\mathrm{CN})\right]$ (22) [19], and $\left(\mathrm{Ph}_{3} \mathrm{P}\right)_{2} \mathrm{Pt}\left[\mathrm{S}_{2} \mathrm{C}=\mathrm{N}(\mathrm{Me})\right]$ (23) [39]) adopt the motif shown in Figure $6 \mathrm{~b}$, as do the analogs with bidentate phosphane ligands, i.e., the R(24) and S-stereoisomers (25) of $\left(\mathrm{Et}_{2} \mathrm{PCH}_{2} \mathrm{CH}_{2} \mathrm{PEt}_{2}\right) \mathrm{Pd}\left[\mathrm{S}_{2} \mathrm{C}=\mathrm{N}(\mathrm{CH}(\mathrm{Me}) \mathrm{Ph})\right]$ [40]). Both 
24 and 25 have two molecules in the asymmetric unit. The two remaining structures, having chelating phosphane ligands, are the direct platinum(II) analogs of the motif shown in Figure 6b, i.e., [ $\left(\mathrm{Ph}_{2} \mathrm{P}\left(\mathrm{CH}_{2}\right)_{3} \mathrm{PPh}_{2}\right) \mathrm{Pt}\left[\mathrm{S}_{2} \mathrm{C}=\mathrm{N}(\mathrm{Ph})\right]$ as the $\mathrm{CH}_{2} \mathrm{Cl}_{2}$ hydrate (26) [38] and (dppf) Pt $\left[\mathrm{S}_{2} \mathrm{C}=\mathrm{N}(\mathrm{CN})\right]$ (27) [19], where dppf is $\mathrm{Ph}_{2} \mathrm{P}\left(\mathrm{C}_{5} \mathrm{H}_{4}\right) \mathrm{Fe}\left(\mathrm{C}_{5} \mathrm{H}_{4}\right) \mathrm{PPh}_{2}$.

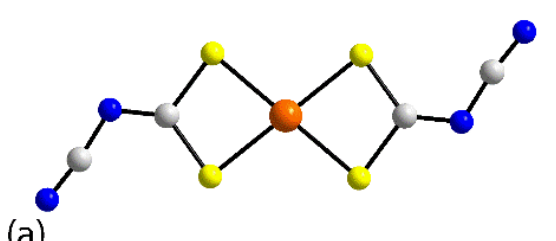

(a)

Figure 6. Molecular structures of (a) the $\left\{\mathrm{Ni}\left[\mathrm{S}_{2} \mathrm{C}=\mathrm{N}(\mathrm{CN})\right]_{2}\right\}^{2-}$ di-anion in $\mathbf{1 0}$ and (b) (dppe) $\mathrm{Ni}\left[\mathrm{S}_{2} \mathrm{C}=\mathrm{N}(\mathrm{CN})\right]$ (12).

\subsubsection{Cu Group}

There are five structures in this category, all containing gold. There is one example of a dinuclear gold(I) complex (i.e., in the salt $\left[\mathrm{Ph}_{3} \mathrm{P}=\mathrm{N}=\mathrm{PPh}_{3}\right]_{2}\left\{\mathrm{Au}\left[\mathrm{S}_{2} \mathrm{C}=\mathrm{N}(\mathrm{CN})\right]\right\}_{2}$ (28) [20]). The di-anion in $\mathbf{2 8}$ (Figure 7a) is a centrosymmetric dimer in which a pair of gold atoms are symmetrically $\mu_{2}$-bridged by two cyanodithiocarbimate ligands (Au-S: $2 \times 2.28 \AA$ ); an intramolecular aurophilic ( $\mathrm{Au} \cdots \mathrm{Au}=2.81 \AA$ ) is noted. The following three salts have the common features of comprising a $\left\{\mathrm{Au}\left[\mathrm{S}_{2} \mathrm{C}=\mathrm{N}(\mathrm{CN})\right]_{2}\right\}^{-}$mono-anion with the gold(III) atom located on a center of inversion within a square planar geometry defined by a $S_{4}$ donor set. The anion in 29 is shown in Figure $7 \mathrm{~b}$. The counter-cations are bis $\left(3,4 ; 3^{\prime}, 4^{\prime}-\right.$ ethylenedithio)-2,2',5,5'-tetrathiafulvalene for 29 [41], the bithieno(3,4-d)-1,3-dithiol radical for 30 [42], and bithieno(3,4-d)-1,3-dithiol for 31 [42], with 31 having co-crystallized with a neutral molecule: bithieno(3,4-d)-1,3-dithiol. The cyano-dithiocarbimate ligands coordinate in the symmetric mode in each case with the range of $\mathrm{Au}-\mathrm{S}$ bond lengths in the three anions ranging from 2.32 to $2.34 \AA$. The fifth structure features a cyclometallated phosphane ligand as illustrated in Figure 7c. In the crystal of $(\mathrm{iPr})_{2} \mathrm{P}\left(\mathrm{C}_{10} \mathrm{H}_{6}-\mathrm{P}, \mathrm{C}\right) \mathrm{Au}\left[\mathrm{S}_{2} \mathrm{C}=\mathrm{N}(\mathrm{Ph})\right]$ (32) [43], the gold(III) atom is $\mathrm{P}, \mathrm{C}$-chelated by the phosphane anion and chelated in a slightly asymmetric fashion by the cyano-dithiocarbimate ligand. The shorter Au-S bond length of $2.34 \AA$ has the sulfur atom trans to the phosphorus atom and the longer bond (2.37 $\AA$ ) trans to the carbon donor. (a)

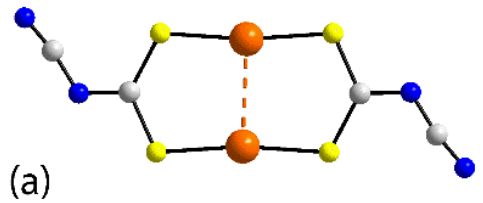

Figure 7. Molecular structures of (a) the $\left\{\mathrm{Au}\left[\mathrm{S}_{2} \mathrm{C}=\mathrm{N}(\mathrm{CN})\right]_{2}\right\}^{2-}$ di-anion in 28, (b) the $\left\{\mathrm{Au}\left[\mathrm{S}_{2} \mathrm{C}=\mathrm{N}(\mathrm{CN})\right]_{2}\right\}^{-}$anion in 29, and (c) $(\mathrm{iPr})_{2} \mathrm{P}\left(\mathrm{C}_{10} \mathrm{H}_{6}-\mathrm{P}, \mathrm{C}\right) \mathrm{Au}\left[\mathrm{S}_{2} \mathrm{C}=\mathrm{N}(\mathrm{Ph})\right]$ in 32. In (a), the orange dashed line indicates an aurophilic $(\mathrm{Au} \cdots \mathrm{Au})$ interaction. 


\subsubsection{Actinides}

There are three thorium structures coordinated by dithiocarbimate ligands. As shown in Figure 8a, in $\left(1,2,4-\mathrm{tBu}_{3} \mathrm{C}_{5} \mathrm{H}_{2}\right)_{2} \mathrm{Th}\left[\mathrm{S}_{2} \mathrm{C}=\mathrm{N}(\mathrm{Ph})\right]$ (33) [44], the central atom is connected to two 1,2,4-tri-t-butyl-cyclopentadienyl ligands as well as a chelating phenyl-dithiocarbimate ligand (Th-S: $2 \times 2.73 \AA$ ); 33 crystallized as an unknown solvate. Additional coordination is noted in $\left(\mathrm{Cp}^{*}\right)_{2} \mathrm{Th}\left(\mathrm{NC}_{5} \mathrm{H}_{4} \mathrm{NMe}_{2}-4\right)\left[\mathrm{S}_{2} \mathrm{C}=\mathrm{N}(\right.$ mesityl)] (34) [45], for which two independent but similar molecules comprise the asymmetric unit. Thus, in addition to two $\mathrm{Cp}^{*}$ anions and a mesityl-dithiocarbimate ligand, the central atom is coordinated by the pyridinenitrogen atom of the 4-dimethylamine-pyridine ligand (Figure $8 \mathrm{~b}$ ). The increase in the coordination number in 34 leads to an elongation of the Th-S bond lengths (i.e., 2.81 and $2.82 \AA$ ) for the chelating ligand compared with the equivalent bonds in 33 .
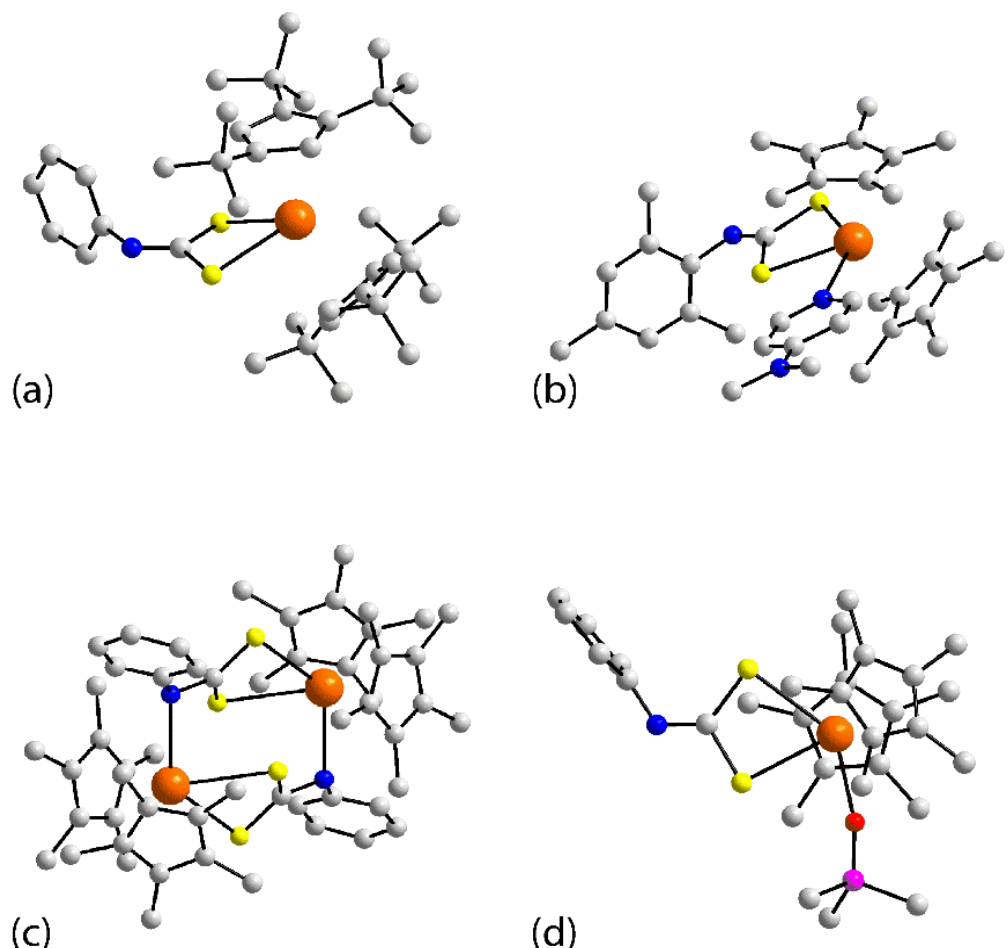

Figure 8. Molecular structures of (a) (1,2,4-tBu $\left.\mathrm{C}_{5} \mathrm{H}_{2}\right)_{2} \mathrm{Th}\left[\mathrm{S}_{2} \mathrm{C}=\mathrm{N}(\mathrm{Ph})\right]$ (33), (b) $\left(\mathrm{Cp}^{*}\right)_{2} \mathrm{Th}\left(\mathrm{NC}_{5} \mathrm{H}_{4} \mathrm{NMe}_{2}-4\right)\left[\mathrm{S}_{2} \mathrm{C}=\mathrm{N}(\right.$ mesityl $\left.)\right]$ (34), (c) $\left\{\left(\mathrm{Cp}^{*}\right)_{2} \mathrm{Th}\left[\mathrm{S}_{2} \mathrm{C}=\mathrm{N}(\mathrm{Ph})\right]\right\}_{2}$ in 35, and (d) $\left(\mathrm{Cp}^{*}\right)_{2} \mathrm{U}\left(\mathrm{O}=\mathrm{PMe}_{3}\right)\left[\mathrm{S}_{2} \mathrm{C}=\mathrm{N}(\mathrm{Ph})\right](38)$.

The exceptional thorium structure is that of di-nuclear $\left\{\left(\mathrm{Cp}^{*}\right)_{2} \mathrm{Th}\left[\mathrm{S}_{2} \mathrm{C}=\mathrm{N}(\mathrm{Ph})\right]\right\}_{2}$, isolated as a benzene mono-solvate (35) [46]. This is readily related to that of 33 in that the bulky t-butyl substituents are substituted by methyl groups. It is likely that the reduction in steric congestion in $\mathbf{3 5}$ allows for dimerization about a center of inversion to generate the di-nuclear species illustrated in Figure 8c. The independent phenyl-dithiocarbimate ligand chelates one thorium atom (Th-S: 2.86 and $2.99 \AA$ ) and connects to the second thorium atom via a Th-N(imine) bond (Th-N: $2.76 \AA$ ). Hence, the phenyl-dithiocarbimate ligand may be considered a rare example of a $\mathrm{k}^{3}$-ligand employing all potential donors in coordination.

Of the three available uranium structures, $\left(1,2,4-\mathrm{tBu}_{3} \mathrm{C}_{5} \mathrm{H}_{2}\right)_{2} \mathrm{U}\left[\mathrm{S}_{2} \mathrm{C}=\mathrm{N}(\mathrm{Ph})\right]$ (36) [47] matches that found for the thorium analog shown in Figure 8a but with shorter U-S bond lengths $(\mathrm{U}-\mathrm{S}: 2 \times 2.68 \AA)$. The structures of $\left(\mathrm{Cp}^{*}\right)_{2} \mathrm{U}\left(\mathrm{O}=\mathrm{PPh}_{3}\right)\left[\mathrm{S}_{2} \mathrm{C}=\mathrm{N}(\mathrm{Ph})\right](37)[48]$ and $\left(\mathrm{Cp}^{*}\right)_{2} \mathrm{U}\left(\mathrm{O}=\mathrm{PMe}_{3}\right)\left[\mathrm{S}_{2} \mathrm{C}=\mathrm{N}(\mathrm{Ph})\right](38)$ [49] are similar, with the latter illustrated in Figure 8d, and 37 was crystallized as a benzene di-solvate. In each structure, the uranium center is additionally coordinated by a phosphane-oxide atom. Small asymmetry is noted in the U-S bond lengths (U-S: 2.76 and $2.78 \AA$ for 37 and 2.75 and $2.78 \AA$ for 38 ). 


\subsubsection{Main Group Elements}

The first two structures in this category are isostructural and conform to the formula $\left[\left(2,6-(\mathrm{iPr})_{2} \mathrm{C}_{6} \mathrm{H}_{3}\right) \mathrm{NC}(\mathrm{Me})=\mathrm{C}(\mathrm{H}) \mathrm{C}(\mathrm{Me})=\mathrm{N}\left(2,6-(\mathrm{iPr})_{2} \mathrm{C}_{6} \mathrm{H}_{3}\right)\right] \mathrm{M}\left[\mathrm{S}_{2} \mathrm{C}=\mathrm{N}(\mathrm{Ph})\right]$, an isolated toluene mono-solvate, for $\mathrm{M}=\mathrm{Al}$ (39) [50] and $\mathrm{M}=\mathrm{Ga}$ (40) [51]; the latter is illustrated in Figure $9 \mathrm{a}$. The central atom is N,N-chelated by a heavily substituted pentane-2,4-diiminate ligand as well as by a symmetrically coordinating phenyl-dithiocarbimate ligand (Al-S: $2 \times 2.23 \AA$; Ga-S: $2 \times 2.26 \AA$ ). The resulting $\mathrm{N}_{2} \mathrm{~S}_{2}$ donor sets define the approximate tetrahedral geometries.

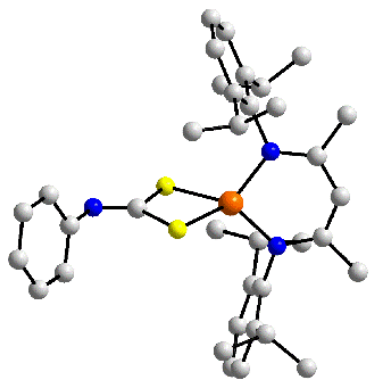

(a)

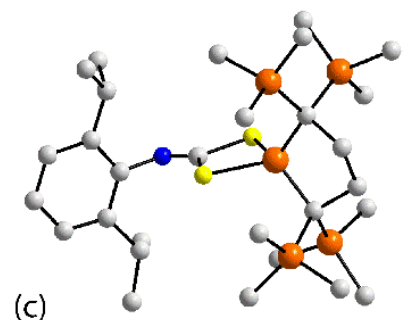

(b)

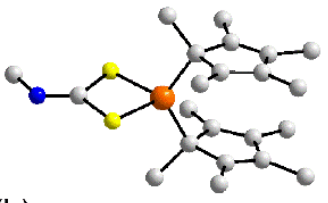

(d)

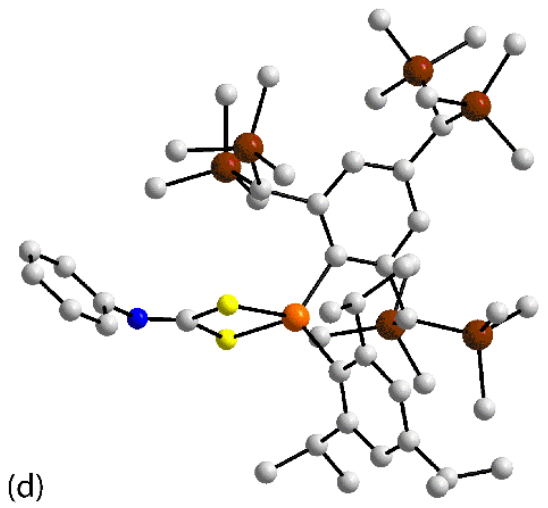

$\begin{array}{lrcccc}\text { Figure 9. Molecular } & \text { structures } & \text { of } & \text { (a) } & {\left[\left(2,6-(\mathrm{iPr})_{2} \mathrm{C}_{6} \mathrm{H}_{3}\right) \mathrm{NC}(\mathrm{Me})=\mathrm{C}(\mathrm{H}) \mathrm{C}(\mathrm{Me})=\mathrm{N}(2,6-\right.} \\ \left.\left.(\mathrm{iPr})_{2} \mathrm{C}_{6} \mathrm{H}_{3}\right)\right] \mathrm{Ga}\left[\mathrm{S}_{2} \mathrm{C}=\mathrm{N}(\mathrm{Ph})\right] & \text { in } & 40, & \text { (b) } \quad\left(\mathrm{C}_{5} \mathrm{Me}_{5}-\mathrm{C}\right)_{2} \mathrm{Si}\left[\mathrm{S}_{2} \mathrm{C}=\mathrm{N}(\mathrm{Me})\right]\end{array}$

$\begin{array}{lccccc}\text { Figure 9. Molecular } & \text { structures } & \text { of } & (\text { a) } & {\left[\left(2,6-(\mathrm{iPr})_{2} \mathrm{C}_{6} \mathrm{H}_{3}\right) \mathrm{NC}(\mathrm{Me})=\mathrm{C}(\mathrm{H}) \mathrm{C}(\mathrm{Me})=\mathrm{N}(2,6-\right.} \\ \left.\left.(\mathrm{iPr})_{2} \mathrm{C}_{6} \mathrm{H}_{3}\right)\right] \mathrm{Ga}\left[\mathrm{S}_{2} \mathrm{C}=\mathrm{N}(\mathrm{Ph})\right] & \text { in } \quad 40, & \text { (b) } \quad\left(\mathrm{C}_{5} \mathrm{Me}_{5}-\mathrm{C}\right)_{2} \mathrm{Si}\left[\mathrm{S}_{2} \mathrm{C}=\mathrm{N}(\mathrm{Me})\right]\end{array}$ (c) $\quad\left[\left(\mathrm{Me}_{3} \mathrm{Si}\right)_{2} \mathrm{CCH}_{2} \mathrm{CH}_{2} \mathrm{C}\left(\mathrm{SiMe}_{3}\right)_{2}-\mathrm{C}, \mathrm{C}\right] \mathrm{Si}\left[\mathrm{S}_{2} \mathrm{C}=\mathrm{N}\left(2,6-(\mathrm{iPr})_{2} \mathrm{C}_{6} \mathrm{H}_{3}\right)\right] \quad(42)$, and $\quad$ (d) $\{2,4,6-$ $\left.\left[\mathrm{C}(\mathrm{H})\left(\mathrm{SiMe}_{3}\right)_{2}\right]_{3} \mathrm{C}_{6} \mathrm{H}_{2}\right\}\left[(2,4,6-\mathrm{iPr})_{3} \mathrm{C}_{6} \mathrm{H}_{2}\right] \mathrm{Ge}\left[\mathrm{S}_{2} \mathrm{C}=\mathrm{N}(\mathrm{Ph})\right](43)$.

The remaining three structures feature central atoms derived from the silicon group and are included for the sake of completeness. In $\left(\mathrm{C}_{5} \mathrm{Me}_{5}-\mathrm{C}\right)_{2} \mathrm{Si}\left[\mathrm{S}_{2} \mathrm{C}=\mathrm{N}(\mathrm{Me})\right]$ (41) [52] (Figure $9 \mathrm{~b}$ ), the silicon atom is coordinated by two carbon atoms derived from a pair of pentamethylcyclopentadienyl ligands and a chelating methyl-dithiocarbimate ligand (Si-S: 2.17 and $2.19 \AA$ ). A similar tetrahedral $\mathrm{C}_{2} \mathrm{~S}_{2}$ donor set is observed for silicon in the structure of $\left[\left(\mathrm{Me}_{3} \mathrm{Si}\right)_{2} \mathrm{CCH}_{2} \mathrm{CH}_{2} \mathrm{C}\left(\mathrm{SiMe}_{3}\right)_{2}-\mathrm{C}, \mathrm{C}\right] \mathrm{Si}\left[\mathrm{S}_{2} \mathrm{C}=\mathrm{N}\left(2,6-(\mathrm{iPr})_{2} \mathrm{C}_{6} \mathrm{H}_{3}\right)\right]$ (42) [53], where the carbon atoms are derived from a chelating ligand (Figure $9 \mathrm{c})$. Again, the $(2,6-$ diisopropylphenyl)-dithiocarbimate ligand is chelating ( $\mathrm{Si}-\mathrm{S}: 2 \times 2.17 \AA$ ). An analogous $\mathrm{C}_{2} \mathrm{~S}_{2}$ donor set is noted for the germanium atom in the final structure to be described, namely $\left\{2,4,6-\left[\mathrm{C}(\mathrm{H})\left(\mathrm{SiMe}_{3}\right)_{2}\right]_{3} \mathrm{C}_{6} \mathrm{H}_{2}\right\}\left[(2,4,6-\mathrm{iPr})_{3} \mathrm{C}_{6} \mathrm{H}_{2}\right] \mathrm{Ge}\left[\mathrm{S}_{2} \mathrm{C}=\mathrm{N}(\mathrm{Ph})\right]$ (43) [54]. The carbon donors in this case are derived from two distinct ligands, and the phenyl-dithiocarbimate ligand is chelating (Ge-S: $2 \times 2.27 \AA$ ) as illustrated in Figure 9d.

\subsection{Comparison between Dithiocarbimate and Dithiocarbamate Structures}

In this section, a comparison of the coordination propensities of di-anionic dithiocarbimate ligands is observed in 1-43 with their mono-anionic dithiocarbamate analogs, when available. Indeed, the first analogs arise for the anion in complex $1,\left\{\mathrm{Mo}(=\mathrm{S})\left(\mu_{2}-\mathrm{S}\right)\left[\mathrm{S}_{2} \mathrm{C}=\mathrm{N}(\mathrm{Ph})\right]\right\}_{2}{ }^{2-}[27]$, such as in the neutral di-nuclear structure of $\left\{\mathrm{Mo}(=\mathrm{S})\left(\mu_{2}-\mathrm{S}\right)\left(\mathrm{S}_{2} \mathrm{CNEt}_{2}\right)\right\}_{2}$ [55]. A very similar molecu- 
lar geometry is noted, and the bond lengths tend to be longer (Mo-S: $2 \times 2.45$ and $2.46 \AA$ cf. $2 \times 2.42$ and $2.46 \AA$ in 1). Analogs are also available for $\left(\mathrm{Ph}_{2} \mathrm{P}\left(\mathrm{CH}_{2}\right)_{2} \mathrm{P}(\mathrm{Ph}) \mathrm{C}_{6} \mathrm{H}_{4} \mathrm{P}(\mathrm{Ph})\left(\mathrm{CH}_{2}\right)_{2}\right.$ $\left.\mathrm{PPh}_{2}\right) \mathrm{W}\left(\mathrm{C} \equiv \mathrm{NC}_{6} \mathrm{H}_{4} \mathrm{Me}-4\right)\left[\mathrm{S}_{2} \mathrm{C}=\mathrm{N}\left(4\right.\right.$-tolyl)] (3 and 4), such as in the cation $\left(\mathrm{Ph}_{2} \mathrm{P}\left(\mathrm{CH}_{2}\right)_{2} \mathrm{P}(\mathrm{Ph})\right.$ $\left.\mathrm{C}_{6} \mathrm{H}_{4} \mathrm{P}(\mathrm{Ph})\left(\mathrm{CH}_{2}\right)_{2} \mathrm{PPh}_{2}\right) \mathrm{W}\left(\mathrm{C} \equiv \mathrm{NC}_{6} \mathrm{H}_{4} \mathrm{Me}-4\right)\left[\mathrm{S}_{2} \mathrm{C}=\mathrm{N}(\mathrm{Me}) 4-\text { tolyl] }\right]^{+}$[29]. In this case, there are small differences between the W-S bond lengths (W-S: 2.54 and $2.55 \AA$ cf. 2.55 and $2.56 \AA$ in 3 ) in the essentially identical structures.

Two structural motifs were noted for the dithiocarbimate complexes of the nickel-triad elements (Section 3.1.5), namely a di-anionic square planar complex within a $S_{4}$ donor set formulated as $\left.[\mathrm{M} \text { (dithiocarbimate })_{2}\right]^{2-}$ and neutral square planar $\left(\mathrm{P}_{2} \mathrm{~S}_{2}\right)$ complexes formulated as $(\mathrm{P})_{2} \mathrm{M}$ (dithiocarbimate), where $(\mathrm{P})_{2}$ equates to two monodentate phosphane ligands or a bidentate phosphane ligand. There are many examples of precedence in the literature of related dithiocarbamate structures found in the CSD [1]. The crucial difference relates to the overall charges in the series of complexes. Thus, $\mathrm{M}$ (dithiocarbamate $)_{2}$ species are neutral, while $\left[(\mathrm{P})_{2} \mathrm{M} \text { (dithiocarbamate) }\right]^{+}$species are mono-cationic. For the former series, with centrosymmetric $\mathrm{Ni}\left(\mathrm{S}_{2} \mathrm{CNEt}_{2}\right)_{2}$ [56] as the prototype structure for comparison, the $\mathrm{Ni}-\mathrm{S}$ bond lengths (i.e., $2 \times 2.20 \AA$ ) are indistinguishable from those in $\mathbf{1 0}$ and $\mathbf{1 1}$ (Table 1). The same observations pertain to $\mathrm{Pd}\left(\mathrm{S}_{2} \mathrm{CNEt}_{2}\right)_{2}$ [57] (i.e., $2 \times 2.32 \AA$ ) and the equivalent $\mathrm{Pd}-\mathrm{S}$ bond lengths in $\mathbf{1 3}$ and $\mathbf{1 4}$ (Table 1 ). A comparison of the Ni-S bond lengths (i.e., $3 \times 2.20$ and $2.21 \AA$ ) for the two independent cations of $\left[(\text { dppe }) \mathrm{Ni}\left(\mathrm{S}_{2} \mathrm{CNEt}_{2}\right)_{2}\right]^{+}$ in its $\left[\mathrm{HgBr}_{4}\right]^{2-}$ salt [58], cf. 12 (Table 1), again reveal a high degree of concordance in the $\mathrm{Ni}-\mathrm{S}$ bond lengths between the two classes of structures. In contrast to the preceding, some evidence for the elongation of the $\mathrm{Pd}-\mathrm{S}$ and $\mathrm{Pt}-\mathrm{S}$ bond lengths in relevant analogs is apparent, as illustrated for a pair of di-nuclear platinum(II) structures. Thus, in each of the centrosymmetric di-cations $\left[\left(\mathrm{Et}_{3} \mathrm{P}\right)_{2} \mathrm{Pt}\left(\mathrm{S}_{2} \mathrm{CN}\left(\mathrm{CH}_{2} \mathrm{CH}_{2}\right)_{2} \mathrm{NCS}_{2}\right) \mathrm{Pt}\left(\mathrm{PEt}_{3}\right)_{2}\right]^{2+}$ and $\left[\left(\mathrm{Ph}_{3} \mathrm{P}\right)_{2} \mathrm{Pt}\left(\mathrm{S}_{2} \mathrm{CN}\left(\mathrm{CH}_{2} \mathrm{CH}_{2}\right)_{2} \mathrm{NCS} 2\right) \mathrm{Pt}\left(\mathrm{PPh}_{3}\right)_{2}\right]^{2+}$ [59], the Pt-S bond lengths of 2.35 and $2.38 \AA$ and 2.35 and $2.36 \AA$, respectively, are longer than their counterparts in 20 and 23 , respectively, Table 1.

Precedence in the literature also exists for several of the gold dithiocarbimate complexes included in the present survey. Thus, neutral di-nuclear $\left[\mathrm{Au}\left(\mathrm{S}_{2} \mathrm{CNEt}_{2}\right)\right]_{2}[60]$ adopts a similar molecular structure but lacks the symmetry of 28 . The $\mathrm{Au}-\mathrm{S}$ bond lengths tend to be longer (e.g., $2 \times 2.29$ and $2 \times 2.30 \AA$ cf. $2 \times 2.28 \AA$ in 28 ), but the intramolecular aurophilic interaction of $2.78 \AA$ is shorter than $2.81 \AA$ in 28 . Such potential for the finetuning of aurophilic interactions is well-known to have implications for the luminescence characteristics of gold complexes [61,62].

The centrosymmetric square planar $\left(\mathrm{S}_{4}\right)$ molecular structures of 29-31 have much precedence in the literature, as exemplified by the salt $\left[\mathrm{Au}\left(\mathrm{S}_{2} \mathrm{CNEt}_{2}\right)_{2}\right] \mathrm{Cl}$ [63]. The Au-S bond lengths in the latter (i.e., $2 \times 2.33 \AA$ ) lie in the range of 2.32-2.34 $\AA$ noted for the Au-S bonds in 29-31.

From the foregoing, several conclusions may be surmised despite the relatively small number of structures available for comparison. First, the presence of two formal changes on the dithiocarbimate ligand allows access to structures not always accessible to analogous dithiocarbamate ligands. When analogs do exist, the overall molecular structures are invariably closely related. Relatively small differences were noted in the magnitudes of the M-S bond lengths occurring in analogous dithiocarbimate and dithiocarbamate molecules, and no definitive trends were discerned. Finally, but crucially, in the latter circumstances where molecules differed only in terms of the presence of dithiocarbimate and dithiocarbamate, the interchange between one or the other allowed control over the charge of the complex molecule, an attribute important, for example, for biological activity [64].

\section{Conclusions}

The synthetic and spectroscopic characteristics along with structural studies of coordination complexes of heavy metal dithiocarbimate complexes were reviewed. Perhaps surprisingly, this is an under-studied class of compound, especially when compared with 
the ongoing research efforts in the analogous chemistry of dithiocarbamate ligands. Coordination normally involves a S,S-chelating mode, with rare examples of tetradentate modes of coordination whereby both sulfur atoms connect to a pair of metal atoms. Even rarer examples of coordination exist in di-nuclear molecules, where the sulfur atoms chelate a metal center and one of the sulfur atoms also links a second metal center. Here, a bridge is formed between the two metals, as each sulfur atom forms a bond with one metal center, one metal is S,S-chelated, and the imine- $\mathrm{N}$ atom connects to a second metal center. In terms of coordination modes and the magnitudes of the $\mathrm{M}-\mathrm{S}$ bond lengths, the structural chemistry of dithiocarbimate and dithiocarbamate are very similar in all respects except, most importantly, in the overall charge on the complex.

Author Contributions: Writing—original draft preparation, review, and editing, P.J.H.; writingoriginal draft preparation, review, and editing, Y.S.T.; writing — original draft preparation, review, and editing, C.I.Y.; conceptualization, writing-original draft preparation, review, and editing, E.R.T.T. All authors have read and agreed to the published version of the manuscript.

Funding: Research in dithiocarbamate chemistry at Sunway University was funded by Sunway University Sdn Bhd, grant number GRTIN-IRG-14-2021. The APC was funded by Sunway University Sdn Bhd.

Conflicts of Interest: The authors declare no conflict of interest.

\section{References}

1. Taylor, R.; Wood, P.A. A million crystal structures: The whole is greater than the sum of its parts. Chem. Rev. 2019, 119, 9427-9477. [CrossRef]

2. Coucouvanis, D. The chemistry of the dithioacid and 1,1-dithiolate complexes. In Progress in Inorganic Chemistry; Lippard, S.J., Ed.; John Wiley \& Sons: Hoboken, NJ, USA, 1970; Volume 11, pp. 234-371. [CrossRef]

3. Eisenberg, R. Structural systematics of 1,1- and 1,2-dithiolato chelates. In Progress in Inorganic Chemistry; Lippard, S.J., Ed.; John Wiley \& Sons: Hoboken, NJ, USA, 1970; Volume 12, pp. 295-369. [CrossRef]

4. Coucouvanis, D. The chemistry of the dithioacid and 1,1-dithiolate complexes, 1968-1977. In Progress in Inorganic Chemistry; Lippard, S.J., Ed.; John Wiley \& Sons: Hoboken, NJ, USA, 1979; Volume 26, pp. 301-469. [CrossRef]

5. Hogarth, G. Transition metal dithiocarbamates: 1978-2003. In Progress in Inorganic Chemistry; Karlin, K.D., Ed.; John Wiley \& Sons: Hoboken, NJ, USA, 2005; Volume 53, pp. 71-561. [CrossRef]

6. Heard, P.J. Main group dithiocarbamate complexes. In Progress in Inorganic Chemistry; Karlin, K.D., Ed.; John Wiley \& Sons: Hoboken, NJ, USA, 2005; Volume 53, pp. 1-69. [CrossRef]

7. Tan, Y.S.; Yeo, C.I.; Tiekink, E.R.T.; Heard, P.J. Dithiocarbamate complexes of platinum group metals: Structural aspects and applications. Inorganics 2021, 9, 60. [CrossRef]

8. Tiekink, E.R.T. Aggregation patterns in the crystal structures of organometallic Group XV 1,1-dithiolates: The influence of the Lewis acidity of the central atom, metal- and ligand-bound steric bulk, and coordination potential of the 1,1-dithiolate ligands upon supramolecular architecture. CrystEngComm 2006, 8, 104-118. [CrossRef]

9. Tiekink, E.R.T.; Zukerman-Schpector, J. Stereochemical activity of lone pairs of electrons and supramolecular aggregation patterns based on secondary interactions involving tellurium in its 1,1-dithiolate structures. Coord. Chem. Rev. 2010, 254, 46-76. [CrossRef]

10. Tiekink, E.R.T. Exploring the topological landscape exhibited by binary zinc-triad 1,1-dithiolates. Crystals 2018, 8, 292. [CrossRef]

11. Tiekink, E.R.T. Perplexing coordination behaviour of potentially bridging bipyridyl-type ligands in the coordination chemistry of zinc and cadmium 1,1-dithiolate compounds. Crystals 2018, 8, 18. [CrossRef]

12. Lee, S.M.; Tiekink, E.R.T. A structural survey of poly-functional dithiocarbamate ligands and the aggregation patterns they sustain. Inorganics 2021, 9, 7. [CrossRef]

13. Tiekink, E.R.T. On the coordination role of pyridyl-nitrogen in the structural chemistry of pyridyl-substituted dithiocarbamate ligands. Crystals 2021, 11, 286. [CrossRef]

14. Lee, S.M.; Heard, P.J.; Tiekink, E.R.T. Molecular and supramolecular chemistry of mono- and di-selenium analogues of metal dithiocarbamates. Coord. Chem. Rev. 2018, 375, 410-423. [CrossRef]

15. Masui, H. Metalloaromaticity. Coord. Chem. Rev. 2001, 219-221, 957-992. [CrossRef]

16. Tiekink, E.R.T.; Zukerman-Schpector, J. Emerging supramolecular synthons: C-H $\cdots \pi($ chelate) interactions in metal bis(1,1dithiolates). Chem. Commun. 2011, 47, 6623-6625. [CrossRef] [PubMed]

17. Tiekink, E.R.T. The remarkable propensity for the formation of $\mathrm{C}-\mathrm{H} \cdots \pi$ (chelate ring) interactions in the crystals of the firstrow transition metal dithiocarbamates and the supramolecular architectures they sustain. CrystEngComm 2020, 22, 7308-7733. [CrossRef]

18. Tiekink, E.R.T. Supramolecular assembly based on "emerging" intermolecular interactions of particular interest to coordination chemists. Coord. Chem. Rev. 2017, 345, 209-228. [CrossRef] 
19. Burchell, C.J.; Aucott, S.M.; Milton, H.L.; Slawin, A.M.Z.; Woollins, J.D. Synthesis and characterisation of cyanodithioimidocarbonate $\left[\mathrm{C}_{2} \mathrm{~N}_{2} \mathrm{~S}_{2}\right]^{2-}$ complexes. Dalton Trans. 2004, 369-374. [CrossRef] [PubMed]

20. Assefa, Z.; Staples, R.J.; Fackler, J.P., Jr. Bis[bis(triphenylphosphoranylidene)-ammonium] bis[cyanodithiocarbimatogold(I)], $[\mathrm{PPN}]_{2}\left[\mathrm{Au}_{2}\left(\mathrm{~S}_{2} \mathrm{CNCN}\right)_{2}\right]$. Acta Cryst. 1995, C51, 2271-2273. [CrossRef]

21. Cotton, F.A.; Harris, C.B. Structure of tetraphenylarsonium bis(N-cyanodithiocarbimato)nickelate(II). Inorg. Chem. 1968, 7, 2140-2144. [CrossRef]

22. Schierl, R.; Nagel, U.; Beck, W. Reactions of transition metal compounds with primary amines and carbon disulfide: Dithiocarbimato and dithiocarbamato complexes of palladium, platinum, nickel, cobalt and gold. X-Ray structure of $\left(\mathrm{Et}_{3} \mathrm{P}\right)_{2} \mathrm{MS}_{2} \mathrm{CNCH}_{2} \mathrm{Ph}$ $(\mathrm{M}=\mathrm{Pd}, \mathrm{Pt})$. Z. Naturforsch. B Chem. Sci. 1984, 39b, 649-660. [CrossRef]

23. Tian, Y.-P.; Duan, C.-Y.; Lu, Z.-L.; You, X.-Z.; Fun, H.-K.; Yip, B.-C. Synthesis and spectral studies of some new palladium(II) and platinum(II) dithio complexes: The novel crystal structure of the palladium(II) dithiocarbimato complex. Polyhedron 1996, 15, 1495-1502. [CrossRef]

24. Adams, R.D.; Captain, B.; Kwon, O.-S.; Miao, S. New disulfido molybdenum-manganese complexes exhibit facile addition of small molecules to the sulfur atoms. Inorg. Chem. 2003, 42, 3356-3365. [CrossRef]

25. Bruno, I.J.; Cole, J.C.; Edgington, P.R.; Kessler, M.; Macrae, C.F.; McCabe, P.; Pearson, J.; Taylor, R. New software for searching the Cambridge Structural Database and visualizing crystal structures. Acta Cryst. 2002, B58, 389-397. [CrossRef] [PubMed]

26. Brandenburg, K.; Berndt, M. DIAMOND, Version 3.2k; GbR: Bonn, Germany, 2006.

27. Mallard, A.; Marrot, J.; Simonnet-Jégat, C.; Sécheresse, F. One-step preparation of dithiocarboimidate ligands by addition of phenylisothiocyanate to tetrathiomolybdate. Inorg. Chim. Acta 2007, 360, 3436-3441. [CrossRef]

28. Ojo, W.-S.; Pétillon, F.Y.; Schollhammer, P.; Talarmin, J. C-C, C-S, and C-N Coupling versus dealkylation processes in the cationic tris(thiolato)dimolybdenum(III) complexes $\left[\mathrm{Mo}_{2} \mathrm{Cp}_{2}(\mu-\mathrm{SMe})_{3} \mathrm{~L}_{2}\right]^{+}(\mathrm{L}=\mathrm{xylNC}, t-\mathrm{BuNC}, \mathrm{CO}, \mathrm{MeCN})$. Organometallics 2008, 27, 4207-4222. [CrossRef]

29. Dai, Q.X.; Seino, H.; Mizobe, Y. Transformations of aryl isothiocyanates on tetraphosphine tungsten complexes and reactivity of the resulting dithiocarbonimidate ligand. Dalton Trans. 2011, 40, 11822-11830. [CrossRef] [PubMed]

30. Schwarz, D.E.; Rauchfuss, T.B. The addition of isocyanides to $\operatorname{ReS}_{4}{ }^{-}:[3+1]$ cycloaddition to $\mathrm{S}=\mathrm{M}=\mathrm{S}$. Chem. Commun. 2000, 1123-1124. [CrossRef]

31. Lohrey, T.D.; Cortes, E.A.; Fostvedt, J.I.; Oanta, A.K.; Jain, A.; Bergman, R.G.; Arnold, J. Diverse reactivity of a rhenium(V) oxo imido complex: [2 + 2] Cycloadditions, chalcogen metathesis, oxygen atom transfer, and protic and hydridic 1,2-additions. Inorg. Chem. 2020, 59, 11096-11107. [CrossRef] [PubMed]

32. Hogarth, G.; O'Brien, M.; Tocher, D.A. Crystal and molecular structures of dppm-bridged diiron dithiolate complexes $\left[\mathrm{Fe}_{2}(\mathrm{CO})_{4}(\mu-\right.$ $\mathrm{SAr}_{2}\left(\mu\right.$-dppm)] $\left(\mathrm{Ar}=\mathrm{Ph}, \mathrm{p}\right.$-tol; $\mathrm{Ar}_{2}=\mathrm{C}=\mathrm{N}-\mathrm{p}$-tol $) . ~ J$. Organomet. Chem. 2003, 672, 29-33. [CrossRef]

33. Schougaard, S.B.; Pittelkow, T.; Krebs, F.; Larsen, S.; Sørensen, H.O.; Greve, D.R.; Bjørnholm, T. Bis(tetra-n-butylammonium) bis[(4-cyanophenyl)dithiocarbimato(2-)-S,S']nickel(II). Acta Cryst. 1998, C54, 470-473. [CrossRef]

34. Singh, A.; Yadav, R.; Kociok-Köhn, G.; Trivedi, M.; Azad, U.P.; Singh, A.K.; Kumar, A. Syntheses of nickel sulfides from 1,2bis(diphenylphosphino)ethane nickel(II)dithiolates and their application in the oxygen evolution reaction. Int. J. Hydrog. Energy 2018, 43, 5985-5995. [CrossRef]

35. Kim, Y.-J.; Jeon, H.-T.; Lee, K.-E.; Lee, S.W. Reactivity of the bis(silyl) palladium(II) complex toward organic isothiocyanates. J. Organomet. Chem. 2010, 695, 2258-2263. [CrossRef]

36. Ahmed, J.; Itoh, K.; Matsuda, I.; Ueda, F.; Ishii, Y.; Ibers, J.A. Structure of bis(triphenylphosphine)(N-ethoxycarbonyldithiocarbimato) palladium(II), formed by the reaction of excess ethoxycarbonyl isothiocyanate with palladium(0) in the presence of triphenylphosphine. Inorg. Chem. 1977, 16, 620-624. [CrossRef]

37. Bon, V.V.; Orysyk, S.I.; Pekhnyo, V.I. cis-(Pyridin-2-ylcarbonimidodithioato- $\kappa^{2}$ S, $\left.S^{\prime}\right)$ bis(triphenylphosphane- $\kappa^{\mathrm{P}}$ )-palladium(II). Acta Cryst. 2011, E67, m46. [CrossRef] [PubMed]

38. Lee, K.-E.; Chang, X.; Kim, Y.-J.; Huh, H.S.; Lee, S.W. Reactivity of bis(silyl)platinum(II) complexes toward organic isothiocyanates: Preparation and structures of (dithiocarbonimidato)- and (diphenylsilanedithiolato)platinum(II) complexes, $\operatorname{cis}-\left[\mathrm{Pt}\left(\mathrm{S}_{2} \mathrm{C}=\mathrm{NPh}\right) \mathrm{L}_{2}\right]$ and cis- $\left[\mathrm{Pt}\left(\mathrm{S}_{2} \mathrm{SiPh}_{2}\right) \mathrm{L}_{2}\right]\left(\mathrm{L}=\mathrm{PMe}_{2} \mathrm{Ph}, \mathrm{PEt}_{3} ; \mathrm{L}-\mathrm{L}=\mathrm{dppp}\right)$. Organometallics 2008, 27, 5566-5570. [CrossRef]

39. Dinger, M.B.; Henderson, W. Insertion reactions of platinum(II) ureylene complexes. J. Chem. Soc. Dalton Trans. 1998, 1763-1773. [CrossRef]

40. Lee, S.G.; Choi, K.-Y.; Kim, Y.-J.; Park, S.; Lee, S.W. Reactivities of organic isothiocyanates and thiocyanates toward dialkyl bis(phosphine) complexes of palladium(II) and platinum(II). Polyhedron 2015, 85, 880-887. [CrossRef]

41. Belo, D.; Rodrigues, C.; Santos, I.C.; Silva, S.; Eusébio, T.; Lopes, E.B.; Rodrigues, J.V.; Matos, M.J.; Almeida, M.; Duarte, M.T.; et al. Synthesis, crystal structure and magnetic properties of bis( 3,$4 ; 3^{\prime}, 4^{\prime}$-ethylenedithio $) 2,2^{\prime}, 5,5^{\prime}$-tetrathiafulvalenebis(cyanoimidodithiocarbonate)aurate(III), (bedt-ttf)[Au(cdc) $)_{2}$. Polyhedron 2006, 25, 1209-1214. [CrossRef]

42. Ribas, X.; Mas-Torrent, M.; Rovira, C.; Veciana, J.; Dias, J.C.; Alves, H.; Lopes, E.B.; Almeida, M.; Wurst, K. Molecular compounds based on DT-TTF and $\mathrm{Au}(\mathrm{cdc})_{2}$ complex. Structural, magnetic and electrical properties. Polyhedron 2003, 22, 2415-2422. [CrossRef]

43. Pujol, A.; Lafage, M.; Rekhroukh, F.; Saffon-Merceron, N.; Amgoune, A.; Bourissou, D.; Nebra, N.; Fustier-Boutignon, M.; Mézailles, N. A nucleophilic gold(III) carbene complex. Angew. Chem. Int. Ed. 2017, 56, 12264-12267. [CrossRef]

44. Zhang, C.; Hou, G.; Zi, G.; Ding, W.; Walter, M.D. A base-free terminal actinide phosphinidene metallocene: Synthesis, structure, reactivity, and computational studies. J. Am. Chem. Soc. 2018, 140, 14511-14525. [CrossRef] [PubMed] 
45. Zhang, C.; Yang, P.; Zhou, E.; Deng, X.; Zi, G.; Walter, M.D. Reactivity of a Lewis base supported thorium terminal imido metallocene toward small organic molecules. Organometallics 2017, 36, 4525-4538. [CrossRef]

46. Yang, P.; Zhou, E.; Fang, B.; Hou, G.; Zi, G.; Walter, M.D. Preparation of $\left(\eta^{5}-C_{5} \mathrm{Me}_{5}\right)_{2} \mathrm{Th}($ bipy) and its reactivity toward small molecules. Organometallics 2016, 35, 2129-2139. [CrossRef]

47. Wang, D.; Wang, S.; Hou, G.; Zi, G.; Walter, M.D. A Lewis base supported terminal uranium phosphinidene metallocene. Inorg. Chem. 2020, 59, 14549-14563. [CrossRef]

48. Wang, D.; Hou, G.; Zi, G.; Walter, M.D. Influence of the Lewis base $\mathrm{Ph}_{3} \mathrm{PO}$ on the reactivity of the uranium phosphinidene $\left(\eta^{5}-\mathrm{C}_{5} \mathrm{Me}_{5}\right)_{2} \mathrm{U}\left(2,4,6-\mathrm{Pr}_{3} \mathrm{C}_{6} \mathrm{H}_{2}\right)\left(\mathrm{OPPh}_{3}\right)$. Organometallics 2021, 40, 383-396. [CrossRef]

49. Wang, D.; Hou, G.; Zi, G.; Walter, M.D. $\left(\eta^{5}-\mathrm{C}_{5} \mathrm{Me}_{5}\right)_{2} \mathrm{U}\left(2,4,6-{ }^{\mathrm{t}} \mathrm{Bu}_{3} \mathrm{C}_{6} \mathrm{H}_{2}\right)\left(\mathrm{OPMe}_{3}\right)$ Revisited-Its intrinsic reactivity toward small organic molecules. Organometallics 2020, 39, 4085-4101. [CrossRef]

50. Chu, T.; Vyboishchikov, S.F.; Gabidullin, B.; Nikonov, G.I. Oxidative cleavage of $\mathrm{C}=\mathrm{S}$ and $\mathrm{P}=\mathrm{S}$ bonds at an $\mathrm{Al}^{\mathrm{I}}$ center: Preparation of terminally bound aluminum sulfides. Angew. Chem. Int. Ed. 2016, 55, 13306-13311. [CrossRef]

51. Kassymbek, A.; Britten, J.F.; Spasyuk, D.; Gabidullin, B.; Nikonov, G.I. Interaction of multiple bonds with NacNacGa: Oxidative cleavage vs coupling and cyclization. Inorg. Chem. 2019, 58, 8665-8672. [CrossRef] [PubMed]

52. Jutzi, P.; Eikenberg, D.; Möhrke, A.; Neumann, B.; Stammler, H.-G. Decamethylsilicocene chemistry: Unprecedented multistep reactions of a silicon(II) compound with the heterocumulenes $\mathrm{CO}_{2}, \mathrm{CS}_{2}$, and $\mathrm{RNCS}(\mathrm{R}=$ methyl, phenyl). Organometallics 1996, 15, 753-759. [CrossRef]

53. Liu, X.; Xiao, X.-Q.; Xu, Z.; Yang, X.; Li, Z.; Dong, Z.; Yan, C.; Lai, G.; Kira, M. Reactions of an isolable dialkylsilylene with carbon dioxide and related heterocumulenes. Organometallics 2014, 33, 5434-5439. [CrossRef]

54. Tokitoh, N.; Kishikawa, K.; Manmaru, K.; Okazaki, R. A Novel reaction of an overcrowded germylene with isothiocyanate leading to formation of the 4-Imino-1,3,2-dithiagermetane ring system. Heterocycles 1997, 44, 149-155. [CrossRef]

55. Huneke, J.T.; Enemark, J.H. The molybdenum:sulfur bond distance in di- $\mu$-sulfido-bis[sulfido(N,N-diethyldithiocarbamato) molybdenum(V)]. Inorg. Chem. 1978, 17, 3698-3699. [CrossRef]

56. Selvaraju, R.; Panchanatheswaran, K.; Thiruvalluvar, A.; Parthasarathi, V. Redetermination of Bis( $N, N$-diethyldithiocarbamato) nickel(II). Acta Cryst. 1995, C51, 606-608. [CrossRef]

57. Beurskens, P.T.; Cras, J.A.; Hummelink, T.W.; Noordik, J.H. Crystal and molecular structure of bis(N,N-diethyldithiocarbamato) palladium(II). J. Cryst. Mol. Struct. 1971, 1, 253-257. [CrossRef]

58. Exarchos, G.; Robinson, S.D.; Steed, J.W. The synthesis of new bimetallic complex salts by halide/sulfur chelate cross transfer: X-ray crystal structures of the salts $\left[\mathrm{Ni}\left(\mathrm{S}_{2} \mathrm{CNEt}_{2}\right)(\mathrm{dppe})\right]_{2}\left[\mathrm{HgBr}_{4}\right],\left[\mathrm{Pt}\left(\mathrm{S}_{2} \mathrm{CNEt}_{2}\right)\left(\mathrm{dppe}_{2}\right]_{2}\left[\mathrm{CdCl}_{4}\right],\left[\mathrm{Co}\left(\mathrm{S}_{2} \mathrm{CNEt}_{2}\right)_{2}\left(\mathrm{dppe}_{2}\right]_{2}\left[\mathrm{Cl}_{3} \mathrm{ZnO}\right.\right.\right.$ : $\left.(\mathrm{Ph})_{2} \mathrm{PCH}_{2} \mathrm{CH}_{2} \mathrm{P}(\mathrm{Ph})_{2}: \mathrm{OZnCl}_{3}\right]$ and $\left[\mathrm{Pd}\left(\mathrm{S}_{2} \mathrm{CN}^{n} \mathrm{Bu}_{2}\right)(\text { bipy) }]_{2}\left[\mathrm{CdCl}_{4}\right]\right.$. Polyhedron 2001, 20, 2951-2963. [CrossRef]

59. Knight, E.R.; Leung, N.H.; Lin, Y.H.; Cowley, A.R.; Watkin, D.J.; Thompson, A.L.; Hogarth, G.; Wilton-Ely, J.D.E.T. Multimetallic arrays: Symmetrical bi-, tri- and tetrametallic complexes based on the group 10 metals and the functionalisation of gold nanoparticles with nickel-phosphine surface units. Dalton Trans. 2009, 3688-3697. [CrossRef]

60. Heinrich, D.D.; Wang, J.-C.; Fackler, J.P., Jr. Structure of $\mathrm{Au}_{2}\left[\mathrm{~S}_{2} \mathrm{CN}\left(\mathrm{C}_{2} \mathrm{H}_{5}\right)_{2}\right]_{2}$, bis(diethyldithiocarbamato)digold(I). Acta Cryst. 1990, C46, 1444-1447. [CrossRef]

61. Schmidbaur, H. The aurophilicity phenomenon: A decade of experimental findings, theoretical concepts and emerging applications. Gold Bull. 2000, 33, 3-10. [CrossRef]

62. Tiekink, E.R.T.; Kang, J.-G. Luminescence properties of phosphinegold(I) halides and thiolates. Coord. Chem. Rev. 2009, 253, 1627-1648. [CrossRef]

63. Lutsenko, I.A.; Ivanov, A.V.; Kiskin, M.A.; Ogil'ko, G.V. Gold(III) ionic complexes $\left[\mathrm{Au}\left\{\mathrm{S}_{2} \mathrm{CN}\left(\mathrm{C}_{2} \mathrm{H}_{5}\right)_{2}\right\}_{2}\right] \mathrm{Cl}$ and $\left.\left(\left[\mathrm{Au}\left\{\mathrm{S}_{2} \mathrm{CN}\left(\mathrm{C}_{2} \mathrm{H}_{5}\right)_{2}\right\}_{2}\right][\mathrm{AuCl}]_{4}\right]\right)_{\mathrm{n}}$ : Synthesis, supramolecular self-assembly, polymorphism, and thermal behavior. Russ. J. Inorg. Chem. 2015, 60, 92-99. [CrossRef]

64. Yeo, C.I.; Tiekink, E.R.T.; Chew, J. Insights into the antimicrobial potential of dithiocarbamate anions and metal-based species. Inorganics 2021, 9, 48. [CrossRef] 